\title{
PENERAPAN MEDIA ANATOMI DALAM PENCIPTAAN PATUNG REALIS (KOP) BAGI MAHASISWA PENDIDIKAN SENI RUPA FBS UNY
}

\author{
Djoko Maruto, MSn. dan Made Aditya Abhiganika \\ Fakultas Bahasa dan Seni, Universitas Negeri Yogyakarta \\ email: joko maruto@uny.ac.id
}

\begin{abstract}
Abstrak
Penelitian ini bertujuan mendiskripsikan pelaksanaan penerapan media anatomi untuk peningkatan kemampuan mahasiswa Seni Rupa dalam penciptaan seni patung realis, meliputi cara memilih bahan yang tepat, penggunaan peralatan yang efesien, penguasaan teknik pembuatan, dan pemerkayaan metode pembelajaran sehingga lebih variatif. Penelitian ini dilakukan di Studio/ruang kelas seni patung pada Jurusan Pendidikan Seni Rupa.

Penelitian ini menggunakan pendekatan kualitatif deskriptif. Pendekatan tersebut digunakan untuk mendapatkan pemahaman yang mendalam tentang pembelajaran anatomi untuk peningkatan kemampuan mahasiswa Seni Rupa dalam penciptaan seni patung realis. Metode kualitatif dipakai sebagai prosedur penelitian yang menghasilkan data deskriptif berupa kata-kata tertulis atau lisan dari orang-orang atau pelaku yang dapat diamati. Pendekatan kualitatif ini diarahkan pada individu secara menyeluruh dalam keutuhan kelas. Relevansi pemilihan pendekatan ini adalah bahwa penelitian kualitatif pada prinsipnya adalah mengamati perilaku orang dalam lingkungan kehidupannya, berinteraksi dengan mereka, dan berusaha memahami aktivitas mereka dengan dunia sekitarnya.

Proses analisis data meliputi reduksi data, penyajian data, dan penarikan kesimpulan/verifikasi sebagai suatu yang jalin-menjalin pada saat sebelum, selama, dan sesudah pengumpulan data berlangsung. Hasil penelitian menunjukan pelaksanaan pembelajaran menggunakan gambar anatomi untuk peningkatan kemampuan mahasiswa Seni Rupa dalam penciptaan seni patung realis: (1).Cara memilih bahan yang tepat; (2) Penggunaan peralatan yang efesien, yaitu alat untuk mematung, yaitu sudip atau butsir; dan (3) Penguasaan teknik mematung dengan menggunakan gambar anatomi yang benar dimulai dari global sampai finishing. Hasilnya mahasiswa mampu membuat karya patung dengan anatomi yang benar dan realis secara mandiri.
\end{abstract}

Kata kunci: gambar anatomi, kemampuan mahasiswa, dalam seni patung realis 
The Application of Anatomy Media in the Creation of Realistic Sculptures for Students of Fine Arts Education Department of FBS UNY

\begin{abstract}
This study aims at describing ways of implementing the application of anatomy media to improve the ability of the students of Fine Arts Education Department to create realistic sculptures. This includes the process of selecting the appropriate material, the use of efficient equipment, the mastery of the techniques for creating scluptures, and the development of the varieties of learning methods. This was conducted in the sclupture studio at Fine Arts Education Department.

This study used descriptive qualitative approach to have the understanding of anatomy learning to improve the ability of the students of Fine Arts Education Department to create realistic sculptures. The qualitative method was used to produce descriptive data in the form of written words or utterances of the observed students. The qualitative approach was aimed at the whole class. The relevance of this approach is that the basic principle of qualitative research is to observe people in their surroundings, interact with them, and try to recognize their activities.

The process of analyzing the data included conducting data reduction, data presentation, and giving conclusion/ verification as a kind of intertwined process at the time before, during, and after the data collection.

The result shows that the learning process using anatomical pictures to improve the ability of the students of Fine Arts Education Department to create realistic sculptures include: 1) the process of selecting the appropriate material; 2) the use of efficient equipment to make sculptures, that is spoons and model objects ; and 3) the mastery of the techniques for creating scluptures by using the right anatomical pictures starting from the global until the finishing process. The result proves that students, without help, are able to make sculptures in the right and realistic anatomy.
\end{abstract}

Keywords: anatomical pictures, students’ ability in realistic scluptures

\title{
A. LATAR BELAKANG MASALAH
}

Jurusan Pendidikan Seni Rupa FBS UNY merupakan Lembaga Pendidikan Tinggi yang mencetak calon guru Seni Rupa profesional. Artinya, pertama ahli dalam bidangnya (expertise), kedua terdapat adanya kesejawatan (corporateness), dan ketiga mempunyai tanggung jawab (responsibility). Agar ketiga hal tersebut dapat tercapai, maka mahasiswa jurusan Pendidikan Seni Rupa diharuskan menempuh sejumlah mata kuliah yang terdapat pada kurikulum jurusan Pendidikan Seni Rupa. 
Mata kuliah Dasar-dasar Seni Patung merupakan salah satu mata kuliah wajib tempuh bagi setiap mahasiswa pada jurusan tersebut, yang peranannya penting bagi calon guru Seni Rupa, karena melalui mata kuliah Dasar-dasar Seni Patung sebenarnya tidak sekedar pembelajaran keterampilan, melainkan juga sebagai sarana untuk pengembangan kreativitas, sensitifitas, dan kemampuan berekspresi, terlebih lagi melalui pembelajaran ini nantinya diharapkan mahasiswa mampu menularkan pengetahuan yang didapatkan kepada masyarakat atau anak didik yang membutuhkan. Dalam proses belajar mengajar, tugas dosen selain memberikan pengetahuan juga memberikan contoh tentang hal-hal yang terkait dengan nilai-nilai (transfer of value) dan memberikan contoh serta menyiapkan hal-hal yang terkait dengan praktik keterampilan (sebagai fasilitator). Untuk efektivitas dan keberhasilan proses belajar mengajar tersebut maka perlu adanya perencanaan pembelajaran dan metode pembelajaran yang tepat serta menciptakan suasana kelas yang kondusif.

Mata kuliah dasar-dasar seni Patung adalah mata kuliah praktik. Setiap mahasiswa diwajibkan membuat patung realis, meliputi pembuatan anggota badan (tangan, kaki), patung kepala (kop), dan patung figur manusia berbagai gerak serta posisi. Diantara semua tugas-tugas tersebut permasalahan yang paling kompleks adalah patung kop/dari masing-masing wajah mahasiswa, karena pada tugas tersebut tidak hanya dituntut permasalahan proporsi, teknik pembuatan dan keluwesannya saja, tetapi juga ketepatan objek dan karakternya. Pembuatan patung kop yang cukup kompleks sangat dipengaruhi oleh pemahaman tentang anatomi wajah yang terkait dengan struktur dan hubungan antar bagian-bagian tubuh manusia yang diajarkan pada mata kuliah Anatomi.

Pengalaman selama mengajar mata kuliah Dasar-dasar Seni Patung, sebagian besar mahasiswa kurang memahami pentingnya fungsi dan peranserta penerapan anatomi dalam pembuatan patung, terutama patung kop, sehingga kemiripan, ketepatan bentuk, dan karakter wajah yang dihasilkan belum tercapai secara maksimal. Berdasarkan permasalahan tersebut maka penerapan media anatomi dalam penciptaan patung realis (kop) bagi mahasiswa Pendidikan Seni Rupa perlu diteliti tingkat efektivitasnya. 


\section{METODE PENELITIAN}

Penelitian ini menggunakan pendekatan kualitatif deskriptif, pendekatan tersebut digunakan untuk mendapatkan pemahaman yang mendalam tentang pelaksanaan pembelajaran anatomi dalam seni patung sebagai salah satu mata kuliah Seni Patung di Prodi Pendidikan Seni Rupa. Subjek penelitian adalah mahasiswa yang mengambil mata kuliah Dasar-dasar Seni Patung 2014-2015 sesuai kurikulum di Pendidikan Seni Patung.

Teknik pengumpulan data dalam penelitian ini menggunakan tes, observasi, catatan lapangan, dan penugasan. Observasi dan catatan lapangan digunakan untuk mengungkap secara deskriptif pelaksanaan pembelajaran seni patung di kelas/studio. Tes dan penugasan digunakan untuk mengungkap penguasaan keterampilan mahasiswa dalam penerapan gambar anatomi, dalam penciptaan seni patung realis.

Teknik analisis data menggunakan deskriptif kualitatatif. Teknik ini digunakan untuk menggambarkan tingkat penguasaan keterampilan mahasiswa dalam penerapan gambar anatomi, dalam mematung dan juga untuk menggambarkan bagaimanakah implementasi tindakan yang dilakukan di kelas maupun studio. Kriteria keberhasilan penelitian tindakan ini adalah mahasiswa memiliki penguasaan keterampilan dalam memilih bahan yang tepat, penggunaan peralatan yang efesien, dan pengguasaan teknik mematung.

Pelaksanaan penelitian ini mengikuti alur penelitian tindakan kelas. Penelitian ini dilakukan melalui empat tahapan sebagai berikut. Tahap pertama, perencanaan. Tim peneliti dan dosen pengampu mata kuliah Seni Patung mendiskusikan permasalahan-permasalahan yang muncul dalam pelaksanaan mata kuliah Seni Patung. Setelah itu, peneliti memasukan materi menggambar anatomi dalam silabus mata kuliah dan mempersiapkan bahan ajar.

Tahap kedua, implementasi tindakan. Tim peneliti dan dosen pengampu memberikan pengantar teoretis kemudian mahasiswa praktik membentuk wajah dengan bahan tanah lihat. Hambatan-hambatan yang dialami mahasiswa didiskusikan untuk dicarikan pemecahannya. Tahap ketiga, observasi dan monitoring. Tim peneliti dan dosen pengampu melakukan observasi, monitoring, evaluasi, dan analisis terhadap pelaksanaan tindakan yang telah dilakukan pada tahap kedua. Untuk observasi dan monitoring digunakan metode observasi, 
catatan lapangan, dan tes. Kriteria keberhasilan tindakan adalah mahasiswa mempunyai keterampilan mematung dengan bentuk patung realis secara benar.

Tahap keempat, refleksi. Tim peneliti dengan dosen pengampu melakukan analisis, sintesis, dan memberi makna pada hasil tindakan pertama untuk kemudian menyimpulkan apakah perlu merevisi, untuk selanjutnya merencanakan kembali jenis tindakan berikutnya yang harus diterapkan agar mahasiswa menguasai teknik pembuatan patung dengan anatomi yang realis. Keempat tahap ini dilakukan secara terus menerus sampai tujuan penelitian tindakan ini dapat tercapai.

\section{HASIL PENELITIAN}

Hasil penelitian dapat ditampilkan dalam tabel berikut ini.

Tabel 1. Deskripsi Kondisi dan Kemajuan Hasil Penelitian

\begin{tabular}{|c|c|c|c|c|}
\hline \multirow{2}{*}{$\begin{array}{c}\text { Aspek } \\
\text { Pengamatan }\end{array}$} & \multicolumn{4}{|c|}{ Deskripsi Kondisi } \\
\hline & Prasurvei & Siklus 1 & Siklus 2 & Siklus 3 \\
\hline $\begin{array}{l}\text { Cara } \\
\text { mengajar } \\
\text { dosen }\end{array}$ & $\begin{array}{l}\text { Dosen } \\
\text { menerangkan } \\
\text { pembelajaran } \\
\text { anatomi } \\
\text { dalam seni } \\
\text { patung secara } \\
\text { umum }\end{array}$ & $\begin{array}{l}\text { Dosen } \\
\text { menjelaskan } \\
\text { bermacam bahan } \\
\text { dan cara memilih } \\
\text { bahan yang tepat } \\
\text { dalam } \\
\text { pembuatan seni } \\
\text { patung }\end{array}$ & $\begin{array}{l}\text { Dosen } \\
\text { menjelaskan } \\
\text { penggunaan } \\
\text { peralatan yang } \\
\text { efesien dalam } \\
\text { pembuatan } \\
\text { seni patung }\end{array}$ & $\begin{array}{l}\text { Tugas pembuatan } \\
\text { karya mulai dari } \\
\text { penguasaan } \\
\text { teknik } \\
\text { pembuatan seni } \\
\text { patung (memilih } \\
\text { bahan, peralatan } \\
\text { dan teknik) }\end{array}$ \\
\hline $\begin{array}{l}\text { Kodisi } \\
\text { keadaan } \\
\text { Mahasiswa } \\
\text { Verbal dalam } \\
\text { PBM }\end{array}$ & $\begin{array}{l}\text { Mahasiswa } \\
\text { banyak } \\
\text { mengadakan } \\
\text { tanya jawab } \\
\text { tentang materi } \\
\text { yang } \\
\text { disampaikan } \\
\text { dosen, ada } \\
\text { keseriusan } \\
\text { mahasiswa } \\
\text { dalam } \\
\text { mengikuti } \\
\text { perkuliahan } \\
\end{array}$ & $\begin{array}{l}\text { Mahasiswa } \\
\text { berusaha } \\
\text { memahami dan } \\
\text { langsung bisa } \\
\text { memilih bahan } \\
\text { yang tepat untuk } \\
\text { pembuatan seni } \\
\text { patung }\end{array}$ & $\begin{array}{l}\text { Mahasiswa } \\
\text { mencoba } \\
\text { peralatan yang } \\
\text { disediakan } \\
\text { dalam } \\
\text { pembuatan } \\
\text { seni patung }\end{array}$ & $\begin{array}{l}\text { Mahasiswa sudah } \\
\text { mulai praktek } \\
\text { secara individu, } \\
\text { mempraktekan } \\
\text { teknik } \\
\text { pembuatan seni } \\
\text { patung mulai } \\
\text { dari (memilih } \\
\text { bahan, alat dan } \\
\text { teknik) }\end{array}$ \\
\hline $\begin{array}{l}\text { Kondisi } \\
\text { keadaan } \\
\text { Mahasiswa } \\
\text { Non Verbal }\end{array}$ & $\begin{array}{l}\text { Mahasiswa } \\
\text { sangat } \\
\text { semangat dan } \\
\text { antusias }\end{array}$ & $\begin{array}{l}\text { Mahasiswa, } \\
\text { sudah dapat } \\
\text { menentukan } \\
\text { bahan yang tepat }\end{array}$ & $\begin{array}{l}\text { Mahasiswa } \\
\text { sangat } \\
\text { semangat dan } \\
\text { antusias }\end{array}$ & $\begin{array}{l}\text { Mahasiswa } \\
\text { sudah mulai } \\
\text { praktek secara } \\
\text { individu, }\end{array}$ \\
\hline
\end{tabular}




\begin{tabular}{|l|l|l|l|l|}
\hline dalam PBM & $\begin{array}{l}\text { dalam } \\
\text { mengikuti } \\
\text { perkuliahan }\end{array}$ & $\begin{array}{l}\text { dalam } \\
\text { pembuatan seni } \\
\text { patung juga } \\
\text { sangat semangat } \\
\text { dan antusias } \\
\text { dalam mengikuti } \\
\text { perkuliahan, } \\
\text { sering terjadi } \\
\text { tanya jawab } \\
\text { antara dosen } \\
\text { dengan } \\
\text { mahasiswa }\end{array}$ & $\begin{array}{l}\text { mencoba } \\
\text { disediakan } \\
\text { dalam } \\
\text { pembuatan } \\
\text { seni patung }\end{array}$ & $\begin{array}{l}\text { mempraktekan } \\
\text { teknik } \\
\text { pembuatan seni } \\
\text { patung mulai } \\
\text { dari (memilih } \\
\text { bahan, alat dan } \\
\text { teknik) } \\
\text { dalam berkarya } \\
\text { sangat semangat } \\
\text { dan antusias } \\
\text { dalam mengikuti } \\
\text { perkuliahan }\end{array}$ \\
\hline $\begin{array}{l}\text { Suasana Kelas } \\
\text { Karena } \\
\text { praktek } \\
\text { suasana kelas } \\
\text { agak ramai, } \\
\text { apalagi materi } \\
\text { baru sehingga } \\
\text { banyak yang } \\
\text { bertanya }\end{array}$ & $\begin{array}{l}\text { Cukup kondusip } \\
\text { mahasiswa sudah } \\
\text { mulai mencoba- } \\
\text { coba, rame } \\
\text { ketika menunggu } \\
\text { antrean } \\
\text { penggunaan } \\
\text { bahan dan alat }\end{array}$ & $\begin{array}{l}\text { Cukup } \\
\text { kondusip } \\
\text { mahasiswa } \\
\text { sangat tertarik } \\
\text { sudah mulai } \\
\text { mencoba-coba } \\
\text { praktek }\end{array}$ & $\begin{array}{l}\text { Cukup kondusip } \\
\text { mahasiswa sudah } \\
\text { mulai berkarya } \\
\text { individu, suasana } \\
\text { cukup terkendali }\end{array}$ \\
\hline $\begin{array}{l}\text { Kemampuan } \\
\text { Mahasiswa } \\
\text { dalam } \\
\text { pembuatan } \\
\text { karya }\end{array}$ & $\begin{array}{l}\text { Belum pernah } \\
\text { membuat } \\
\text { karya }\end{array}$ & $\begin{array}{l}\text { Sudah } \\
\text { memahami } \\
\text { tentang bahan }\end{array}$ & $\begin{array}{l}\text { Sudah } \\
\text { memahami } \\
\text { tentang } \\
\text { peralatan yang } \\
\text { digunakan }\end{array}$ & $\begin{array}{l}\text { Sudah } \\
\text { menghasilkan } \\
\text { karya secara } \\
\text { individu dan } \\
\text { sudah ada } \\
\text { hasilnya }\end{array}$ \\
\hline
\end{tabular}

\section{Laporan Siklus-siklus Penelitian}

Sebelum ditentukan siklus penelitian terlebih dahulu dilakukan prasurvei, hal ini merupakan suatu rangkaian penelitian awal untuk mengetahui kelayakan masalah yang akan diteliti setelah didapat data-data yang jelas baru kemudian menentukun siklus-siklus penelitian. Hasil prasurvei dilaksanakan dengan melibatkan langsung dosen pengampu mata kuliah dengan cara menerangkan pembelajaran teknik seni patung secara umum, mahasiswa banyak mengadakan tanya jawab tentang materi yang disampaikan dosen, ada keseriusan mahasiswa dalam mengikuti perkuliahan karena materinya boleh dikatakan baru, sehingga mahasiswa sangat semangat dan antusias dalam mengikuti perkuliahan, prasurvei dilakukan pada kuliah pertama, setelah diketahui tahap prasurvei permasalahan yang ada baru kemudian menyusun siklus-siklus. Penelitian ini dilakukan melalui tiga siklus sebagai berikut. 
Siklus pertama difokuskan pada bahan pembuatan seni patung. Dalam siklus ini dimulai dari perencanaan. Dosen dan mahasiswa sepakat merencanakan pemberian teori umum tentang pembuatan seni patung. Setelah itu, dosen menjelaskan bermacam bahan dan cara memilih bahan yang tepat dalam pembuatan seni patung, mulai dari bahan pokok sampai bahan pembantu dengan menggunakan media pembelajaran berupa contoh-contoh, seperti hasil karya seni patung. Mahasiswa mendengarkan dan berusaha untuk tanya jawab. Pada kesempatan ini mahasiswa sudah mulai mencoba mengenali bahan yang digunakan, dengan memegang bahan/media yang dibawa dosen.

Para mahasiswa merasa puas dan penuh semangat untuk mengikuti perkuliahan. Setelah itu, peneliti mendiskusikan permasalahan-permasalahan yang muncul dalam pelaksanaan mata kuliah seni patung sebagai bagian dari tahap observasi dan analisis. Tahap berikutnya tim peneliti melakukan refleksi dari perkuliahan. Pada tahap ini peneliti berkesimpulan untuk memasukan teknik seni patung dalam silabus mata kuliah Seni Patung. Setelah mempersiapkan bahan ajar teknik seni patung. Hasil yang diperoleh dalam siklus ini yaitu adanya respon mahasiswa dengan baik tentang penguasan bahan seni patung, kemudian diteruskan ke siklus berikutnya.

Siklus kedua difokuskan pada peralatan. Sebagai tindak lanjut siklus pertama maka siklus kedua dimulai dari perencanaan. Dosen dan mahasiswa membuat rencana mengenai PBM menyangkut masalah peralatan yang dibutuhkan dalam pembuatan seni patung realis. Dosen menjelaskan penggunaan peralatan yang efisien dalam pembuatan seni patung kemudian sebagai implementasinya mahasiswa mencoba peralatan yang disediakan oleh dosen, dalam pengenalan peralatan pembuatan seni patung ini mahasiswa sangat semangat dan antusias mencoba peralatan yang disediakan dalam pembuatan seni patung, suasana kelas cukup kondusif, mahasiswa sangat tertarik, dan sudah tidak sabar untuk memulai praktik.

Pada siklus ini mahasiwa sudah mulai mencoba-coba praktik. Setelah itu, diadakan observasi dan diskusi mengenai materi yang sudah disampaikan. Hasil observasi dan diskusi menunjukkan bahwa mahasiswa sudah memahami peralatan yang digunakan dalam pembuatan seni patung. Sebagai refleksi tindakan, tim peneliti dan dosen pengampu memberikan pengantar teoretis. Selanjutnya 
mahasiswa praktik mencoba peralatan seni patung. Hambatan-hambatan yang dialami mahasiswa didiskusikan untuk dicarikan pemecahannya. Pencapaian yang diperoleh yaitu mahasiwa mampu menguasi peralatan seni patung, meskipun masih dibawah bimbingan dosen. Setelah menguasai peralatan seni patung, mahasiswa akan diarahkan untuk menguasai teknik seni patung.

Siklus ketiga difokuskan pada teknik pembuatan seni patung. Setelah tahap perencanaan untuk siklus ketiga, dosen memberikan teori dan praktik teknik pembuatan. Setelah itu, pada tahap implementasi mahasiswa sudah mulai praktik secara individu. Mahasiswa mempraktikkan teknik pembuatan seni patung mulai dari memilih bahan, peralatan, dan teknik. Tahap berikutnya diadakan observasi dan diskusi tentang jalannya perkuliahan seni patung. Hasil yang diperoleh, mahasiswa dalam berkarya sangat semangat dan antusias dalam mengikuti perkuliahan. Suasana kelas cukup kondusif. Mahasiswa sudah mulai berkarya individu. Mahasiswa mulai menghasilkan karya secara individu dan sudah ada hasilnya tugas pembuatan karya. Berdasarkan kriteria keberhasilan tindakan, mahasiswa mulai menguasai keterampilan mematung dengan menggunakan teknik seni patung dengan benar. Hasil siklus ini menunjukan kemampuan mahasiswa meningkat pesat dalam pembuatan karya patung dengan menggunakan seni patung.

Setelah siklus-siklus tersebut terlaksana, maka diadakan monitoring evaluasi dan analisis terhadap pelaksanaan tindakan yang telah dilakukan dari tim peneliti dan dosen pengampu. Pada tahap refleksi, tim peneliti dengan dosen pengampu melakukan analisis, sintesis, dan memberi makna pada hasil tindakan yang telah dilakukan untuk menyimpulkan apakah perlu merevisi, merencanakan kembali jenis tindakan berikutnya yang perlu diterapkan agar mahasiswa menguasai teknik seni patung. Keempat tahap ini dilakukan secara terus menerus sampai tujuan penelitian tindakan ini dapat tercapai.

Hasil siklus ini menunjukan kemampuan mahasiwa meningkat baik dalam kualitas dan kuantitas karya yang dihasilkan. Hal ini dapat dibuktikan dengan antusias mahasiswa dalam membuat karya secara berkesinambungan. Begitu karya pertama jadi, mahasiswa akan berkarya lagi, sehingga karyanya bertambah terus dengan kualitas karya yang semakin meningkat. 


\section{Pembahasan}

Penelitian ini dilakukan di Prodi Pendidikan Seni Rupa FBS UNY, diteliti hanya mata kuliah Dasar-dasar Seni Patung. Pilihan terhadap mata kuliah ini dilakukan karena mahasiswa baru mulai mengenal seni patung dan anatomi. Disamping itu, diharapkan mahasiswa yang mengikuti mata kuliah ini mampu membuat karya dengan teknik seni patung. Karya tersebut diharapkan sekaligus dapat dimatangkan sebagai karya tugas akhir karya seni. Penelitian ini difokuskan pada pemilihan bahan, peralatan, dan teknik dalam seni patung.

Sebelum penelitian dilaksanakan terlebih dahulu diadakan perencanaan, tim peneliti dan dosen pengampu mata kuliah seni patung mendiskusikan permasalahan-permasalahan yang muncul dalam pelaksanaan mata kuliah seni patung. Kemudian peneliti memasukan teknik penciptaan seni patung dalam silabus mata kuliah seni patung. Setelah itu mempersiapkan bahan ajar penciptaan seni patung.

Hasil yang diperoleh dalam penelitian ini yaitu adanya respon mahasiswa dengan baik tentang penciptaan seni patung, kemudian disesuaikan dengan silabus, sebagai implementasi tindakan, tim peneliti dan dosen pengampu memberikan pengantar teoretis kemudian mahasiswa praktik membuat karya patung dengan teknik aditif/modeling. Hambatan-hambatan yang dialami mahasiswa didiskusikan untuk dicarikan pemecahannya. Pencapaian yang diperoleh yaitu mahasiwa mampu membuat suatu patung dengan teknik seni patung yang layak pajang/dipamerkan.

Monitoring dilakukan tim peneliti dan dosen pengampu secara terus menerus selama penelitian berlangsung kemudian dilakukan evaluasi dan analisis terhadap pelaksanaan tindakan yang telah dilakukan. Kriteria keberhasilan tindakan adalah mahasiswa mempunyai keterampilan mematung dengan menggunakan teknik modeling. Sebagai refleksi, tim peneliti dengan dosen pengampu melakukan analisis, sintesis, dan memberi makna pada hasil tindakan yang sudah dilaksanakan, kemudian menyimpulkan apakah perlu merevisi, merencanakan kembali jenis tindakan berikutnya yang perlu diterapkan agar mahasiswa menguasai teknik seni patung.

Pelaksanaan pengamatan ini dilakukan secara terus menerus sampai tujuan penelitian tindakan ini dapat tercapai. Hasil penelitian menunjukan kemampuan 
mahasiwa meningkat baik dalam kualitas dan kuantitas karya yang dihasilkan, dari karya-karya hasil praktik membuktikan mahasiswa sudah mampu membuat karya sesuai dengan yang diharapkan. Antusias mahasiswa dalam mengikuti kuliah juga semakin meningkat. Mahasiswa sudah menghasilkan karya secara individu yang siap dipamerkan.

\section{KESIMPULAN}

Berdasarkan hasil penelitian dan pembahasan di atas dapat disimpulkan bahwa pelaksanaan penerapan gambar anatomi dalam pembelajaran penciptaan seni patung. Seni patung pada mahasiswa sudah berjalan dengan baik meliputi beberapa hal sebagai berikut.

1. Cara memilih bahan yang tepat, yaitu menggunakan bahan tanah liat (lempung), gips.

2. Penggunaan peralatan yang efisien, yaitu alat pahat, alat potong dari kawat.

3. Penguasaan teknik pembuatan dimulai dari bagaimana memilih bahan, Membentuk secara global, membentuk detail sampai menjadi karya.

Hasilnya mahasiswa sudah mampu membuat karya mandiri dalam berkarya dengan teknik modeling dengan anatomi yang benar.

\section{Daftar Pustaka}

Bastomi, Suwaji. (1992). Wawasan Seni. Semarang: IKIP Semarang Press

Dimyati, (1999).Belajar dan Pembelajaran. Jakarta:Rineka Cipta

Departemen P. \& K.(1991). Ensiklopedia Nasional Indonesia. Jakarta: PT Cipta Adi Pustaka

Miles dan Hubermen.1992. Analisis Data Kualitatif. (Terjemahan Tjetjep Rohendi). Jakarta:UI Press

Moleong, L. J.(1991). Metodologi Penelitian Kualitatif. Bandung: PT Remaja Rosdakarya

Nicolich, Wool Folk.(1980). Teaching and Educational Psychology. New Jersey: Englewood Cliffs 
Nasution, S. (2000). Metode Research ( penelitian Ilmiah). Jakarta: Bumi Aksara

Sudarmaji (1973). Dasar-dasar Kritik Seni Rupa. Yogyakarta: STSRI”ASRI

Susanto Mikke (2002), Diksi Rupa Kumpulan Istilah Seni Rupa, Kanisius Yogyakarta

Sachari Agus, (1986).Pradigma Desain Indonesia, Jakarta ,Rajawali

Soedarso SP. (1990). Tinjauan Seni. Yogyakarta: Saku Dayar Sana Yogyakarta.

Walizer, M. dan Wienir, P ( 1991) Metode dan Analisis Penelitian (terj. Sadiman, A. S.). Jakarta: Erlangga.

Zamroni (2000), Pradigma pendidikan masa depan Yogyakarta

UU RI No.2 Tahun 2003 Tentang Sistem Pendidikan Nasional 
52 (mol, Vol. 13, No. 1, Februari 2015 : 41 - 52 